\title{
Shakespeare Cut and Refashioned: The Ukrainian Translation of Hamlet Made by Hnat Khotkevych (1920s)
}

\begin{abstract}
Shakespeare's Hamlet has always been an attractive challenge for the Ukrainian translators. For now there are more than a dozen variants, and some of them have entered the treasury of the Ukrainian Shakespeareana. It is worth mentioning that the vast majority of these translations were made disregarding the perspective of a production. Only three Ukrainian 'Hamlets' were created for the stage, and the almost forgotten translation by Hnat Khotkevych is among them.

Although this version was intended for performance, none of its words have ever been pronounced from the stage. Hnat Khotkevych, a renowned Ukrainian musician, writer and theatre practitioner of the 1900s-1930s completed his translation to bring Shakespeare closer to ordinary people. He was deeply convinced that Shakespeare's dramatic legacy had to be partly ignored to make it suitable for a stage production in Ukraine in the early $20^{\text {th }}$ century. That democratic intention of the translator resulted in a dramatic simplification of the original text. The technique, employed by Hnat Khotkevych, meant, first of all, cutting the dramatis personae of Fortinbras, Voltimand, Cornelius; the gravediggers never appear in this version either. Besides, the translator, firmly believing that Ukrainian actors of his time were totally incapable of reciting Shakespeare's poetic verse, transformed the Bard's iambic pentameter into prose. In his translation, Shakespeare's tragedy acquired specific linguistic and stylistic features of a typical Ukrainian play of the late $19^{\text {th }}$-early $20^{\text {th }}$ century, much like Khotkevych's own dramas.
\end{abstract}

Keywords: Shakespeare, Hamlet, Hnat Khotkevych, translation, domestication, stage production

The tragedy of the Prince of Denmark has a long and painful history of translation into Ukrainian,which started in the second half of the $19^{\text {th }}$ century. According to Olha Luchuk, ${ }^{1}$ the first known attempt of translating it was made by Pavlyn Sventsytskyi, who was able to render only Act 1 in 1870, the first full Ukrainian

1 О. Лучук, Діалогічна природа літератури. Перекладознавчі та літературознавчі нариси, Львів 2004, с. 94. 
version of Hamlet was provided by Yosyp Yurii Fedkovych. ${ }^{2}$ By the end of the $19^{\text {th }}$ century, Ukrainian literary space could boast two more remarkable versions of themost famous Shakespearean tragedy - those made by Mykhailo Starytskyi and Panteleimon Kulish. ${ }^{3}$ Due to the prohibition to publish books in Ukrainian, which was valid in the Russian Empire of that time, those versions were printed in the territories that belonged to the Austrian-Hungarian Empire. However, none of the $19^{\text {th }}$ century translations were intended for the stage; this was absolutely unthinkable under the circumstance of the total suppression of the Ukrainian culture by the two neighboring giants.

The so-called 'golden era' for the Ukrainian Hamletiana was observed in the first half of the $20^{\text {th }}$ century, when practically every decade at least one new translation appeared. The versions created by such outstanding men of ink and pen as Yurii Klen (Osvald Burghardt), Leonid Grebinka, Mykhailo Rudnytskyi, Grygorii Kochur and others had different, though mainly undeservingly tragic destinies: from an anonymous publication in a school collection of world literature texts (Yurii Klen) to long lasting oblivion, caused mainly by Stalin repressions, and heavily censored release forty years later (Leonid Grebinka). ${ }^{4}$

It is worth mentioning that, out of more than a dozen Ukrainian versions of Hamlet,only three were created with a stage production in mind. The latest was done by the celebrated Ukrainian author Yurii Andrukhovych for the Kyiv Molodyi Teatr (The Young Theatre) in the late 1990s - early 2000s..$^{5}$ That post-modern version of Shakespeare's tragedy, which balanced on the edge between conventionalism and kitsch, received very ambiguous critical response - the translator was criticized for his remarkably brutal vocabulary and for, as it seemed to some of the reviewers, the purposeful violation and burlesque of the Bard's masterpiece. The phenomenon of Andrukhovych's translation and its meaning for millennial Ukraine is best explained by Lada Kolomiets:

Obviously, this translation should be viewed not from the hermeneutic position of the translator's self-projection onto the artistic personality of the author, but rather as a refashioning of the original text, as an example of phenomenological freedom in the interpretation of a classic text with a clearly marked orientation on the colloquial culture of the recipient. This translation is declaratively (sometimes - even aggressively, taking into account the number of obscene words) populist, created for massive stage reception. Thus, this translation should be viewed not only as an artistic but also as a social statement by Andrukhovych... ${ }^{6}$ (transl. - D.M.)

An earlier Ukrainian translation of the Danish tragedy for the stage, made in the early 1940 s by a Lviv scholar, Mykhailo Rudnytskyi, was a crucial element

2 М. Мороз, В. Шекспір в Украӥнській РСР, в: В. Шекспір, Твори в шести томах, том 6, Київ 1988 , с. 804.

3 Ibid., c. 804-806.

4 Л. Коломієць, Украӥнські перекладачі «Гамлета» В. Шекспіра: Пантелеймон Куліш, Юрій Клен, Леонід Гребінка, Михайло Рудницький, Ігор Костецький, Григорій Кочур, Юрій Андрухович, "Ренесансні студії” 2009, по. 12-13, с. 163-188.

5 This translation was first published in the literary journal "Четвер" (Chetver) in 2000.

6 Л. Коломієць, Новий украйнський “Гамлет”": перекладацька стратегія Ю. Андруховича, “Мова і культура" 2005, vol. 8, no. 3 (2), с. 354. 
in the history of Ukrainian Hamletiana, as it was used purposefully for the first full Ukrainian production of Hamlet ever. ${ }^{7}$ The first appearance of the Prince of Denmark on the Ukrainian stage took place in 1943 in Lviv, under the dramatic circumstance of the Nazi occupation. The director Yosyp Hirniak, who was one of the most talented disciples of the celebrated theatrical innovator Les Kurbas, constructed his performance taking into account all the political contexts of the day, especially the fact that Ukraine was bleeding, being torn between Nazi Germany and the USSR. Such a stage concept totally excluded the possibility of using the already existing so-called 'text-centered' Hamlet translations, and strictly demanded a brand-new version, which could be a certain 'mirror' of the day. Thus, in his translation, Mykhailo Rudnytskyi employed various wordplay techniques, hidden hints and intertextual elements, aimed at creating 'links' between the events in medieval Denmark and war-time Ukraine. Anastasia Vasylyk-Furman stresses its outstanding performability, which was due to the adequate translation of the key moments in the text. ${ }^{8}$ Contemporary critics also highly praised that artistic experiment; I. Nimchuk, a celebrated theatre critic of that period, wrote,

There wasn't a spectator who would not admit that the translation was great and comprehensible and clear for everybody. Indeed, that version was made with the idea of a stage production; it can become a reference for translations of other classic plays into Ukrainian ${ }^{9}$ (transl. - D.M.).

The fate of Mykhailo Rudnytskyi's Hamlet was quite common for many Ukrainian translations of that period: it was lost in oblivion for many years and not even a single copy survived in Ukraine. It took a lot of really heroic and enthusiastic work of the Department of Theatre Studies and Acting ("Ivan Franko" National University in Lviv) to retrieve its full version from the USA, ${ }^{10}$ where some of the actors, employed in Yosyp Hirniak's production, had emigrated.

However, the very beginning of the dramatic history of the Ukrainian translations of Hamlet for the stage is not connected with the daring performance of 1943, but with the activity of one of the most celebrated Ukrainian artists of the first half of the $20^{\text {th }}$ century - Hnat Khotkevych (1877-1938). The impressive diversity of his creative legacy allows us to call him a true Renaissance man. He was equally good as a theatre practitioner (during 1895-1930s he founded and developed several professional and amateur theatres, and his most famous project, Hutsul folk theatre, established in 1910, is still operating), as a musician (he was a virtuoso of Ukrainian folk instruments and compiled a set of guidebooks for bandura players), as a writer (he was the author of numerous

7 Л. Коломієць, ор. cit., с. 166

8 А. Василик-Фурман, Трагедія В. Шекспіра «Гамлет» у перекладі М. Руднищького, в: В. Шекспір, Гамлет, Львів 2008, с. 16.

9 Б. Козак, Палімпсест украӥнського «Гамлета: переклад Михайла Рудницького і прапрем'єра у Львові 1943 року, in: В. Шекспір, Гамлет, ор. cit., с. 177.

10 This newly found translation was first published in the journal "Просценіум" ("Рroscaenium" 2004, no. 1-2) without the final scenes of Act 1 and Act 5. The completely restored version was printed in Lviv in 2008. 
novels, plays and short stories selections) and as a translator (he translated plays by Shakespeare, Molière, Lope de Vega and Schiller into Ukrainian).

Khotkevych made use of quite an unconventional approach to literary translation. It was fully subordinated to his major activity, which was the theatre: his translator's portfolio comprises only dramas, and Shakespeare's plays form its major part. Khotkevych was the author of the Ukrainian versions of Hamlet, Romeo and Juliet, Macbeth, The Comedy of Errors, The Taming of the Shrew and The Merry Wives of Windsor. His translation method was also determined by theatrical practice. It is obvious that he was quite indifferent to maintaining adequacy of his translation or rendering carefully Shakespeare's poetic language into Ukrainian. The main aim of the translation of the classic dramas was, in his opinion, to make them suitable for productions on the Ukrainian stage of the time. That, by the way, might be one of the reasons for the so-called 'secondariness' of Hnat Khotkevych in the gallery of other celebrated Ukrainian translators: being concentrated mainly on the scenic side of his versions, he never strived for their publication, that is why the majority of them are still manuscripts and are stored in the Lviv branch of the Central Ukrainian Reference Archive. ${ }^{11}$

Lack of recognition in Khotkevych's lifetime resulted in considerable difficulty for present-day attempts to reconstruct his personality of a translator. He translated from four major European languages - English, French, German and Spanish - but it is not known exactly when, where and how he was able to learn them. He was born to a family of peasants ${ }^{12}$ who could hardly afford private tutors of foreign languages for their son. His education was surprisingly different from his true vocation of a folk musician and theatre practitioner: he graduated from the Kharkiv non-classic secondary school in 1894 and from the Kharkiv Technological Institute in $1900 .{ }^{13}$ He was likely to learn French and German at school, as these subjects were typically included in the curriculum of that type of school, ${ }^{14}$ however, his command of English and Spanish is unknown. Besides, there are no mentions of the sources of the original texts he might have used. It is quite possible that Khotkevych referred not (only) to Shakespeare's originals but rather to other translations. Olha Luchuk suggests that he might have made use of the already published Ukrainian translations of Hamlet made by Fedkovych, Starytskyi and Kulish. ${ }^{15}$ The fact that Khotkevych conveyed Shakespeare's iambic pentameter in prose can provoke a conclusion

11 By now, Hamlet is the only published translation of a Shakespeare's tragedy made by Khotkevych. It first appeared in the journal "Парадигма" ("Paradygma") in 1998. His translations of Shakespeare's comedies (The Comedy of Errors, The Taming of the Shrew and The Merry Wives of Windsor) were published in Kharkiv in 1924-1928. The latter one was characterized as 'adaptation' in D. Doroshenko's paper Shakespeare in Ukrainian (1931), p. 712.

12 Т. Самчинська, Гнат Хоткевич: німецький шпигун із бандурою, “Друг читача," https:// vsiknygy.net.ua/person/5962/.

13 В. Кізченко, Хоткевич Гнат Мартинович, в: Енциклопедія історії Украӥни, у 10 томах, том 10: Т-Я, Київ 2013, с. 424.

14 Реальные училища, Энциклопедический словарь Брокгауза и Ефрона, https://ru.wikisource. org/wiki/ЭСБЕ/Реальные_училища

15 О. Лучук, Діалогічна природа, ор. cit., с. 199. 
that he may have also used French translations of the Bard's greatest tragedy, for example, those by Pierre Le Tourneur, Benjamin Laroche, Émile Montégut. However, this is hardly possible because the first Ukrainian encounters with Shakespeare took place when the country was divided between two empires Austro-Hungarian and Russian, so the main mediators were German and Russian translations. ${ }^{16}$

Hnat Khotkevych's wish "to adapt Shakespeare's Hamlet to the theatre, to its reception in stage performance" ${ }^{17}$ seems more than paradoxical - what is the point of a theatrical abridging of a text which had been initially created for the stage? However, the clue to such an approach is in Khotkevytch's review of Les Kurbas' Macbeth, which was produced in Kharkiv in 1924. Analysing the performance of his disciple, Khotkevych criticized the extensive employment of declamation in the performance. He wrote,

As we know Shakespeare wrote in the late XVI - early XVII centuries, when the art of acting was substituted by the art of declamation that is why all Shakespeare's soliloquies are purely declamatory. Now we cannot and don't want to recite, though we leave Shakespeare's soliloquies unaltered. So, an actor or an actress has to compensate with various 'original' movements. But whatever you do, you cannot fill a long monologue with sense. ${ }^{18}$

Obviously, Hnat Khotkevych expressed his own ideas on how to stage the Bard's plays in the early $20^{\text {th }}$ century. He was deeply convinced that the use of Shakespeare's 'unabridged' text added a certain affectation and unnaturalness to the performance, as the lengthy and grand-sounding utterances of the tragic heroes did not correspond to the dynamic aesthetics of that period. Promoting the idea that the actors of his time were unable to recite long rhymed Shakespearean monologues, he not only rendered them in prose, but shortened them, removing the poetic component and keeping only their sense, but not their stylistic features. Moreover, Khotkevych cut some plotlines and removed some side characters, which was perhaps necessary for the production, but fully wrong for the translation itself.

All the above mentioned techniques were widely employed in the translation of Hamlet. ${ }^{19}$ The text is a scenario rather than a translation proper, as the original text is cut, shortened, and its stylistic component is inadequately rendered. First of all, according to a popular tendency of the time, Khotkevych reduced the list of dramatis personae: Voltimand, Cornelius and, the most important, Fortinbras were excluded from the play. The absence of the Norwegian prince obviously limited the interpretative potential of the translation which became deprived of the major political aspect.

16 Ю. Черняк, Специфіка актуалізації иіннісної семантики «Гамлета» В. Шекспіра в українському шекспірівському дискурсі, Київ 2011, с. 8.

17 О. Лучук, Діалогічна природа, ор. cit., с. 99.

18 Л. Ковальчук, 3 приводу однієї постановки (рецензія Гната Хоткевича на «Макбет» Леся Курбаса), http://www.kurbas.org.ua/projects/almanah7/14_1_k.pdf, c. 165.

19 It is impossible to properly establish the date of its completion. Olha Luchuk (2004) presumes that it was finished in the 1920s, when Khotkevych actively implemented his theatrical experiments. However, it is highly unlikely that the translation has ever been staged. 
As already stated, the translator cut off some important side plot lines and scenes, thus making the main conflict more contrastive and one-dimensional at the same time. For instance, Ophelia does not die here, at least the reader/the spectator is not informed about her death. Consequently, the graveyard scene, the gravediggers and the dialogue of Hamlet and Horatio on the sense of human existence are missing, thus diminishing the philosophical component of the tragedy.

By reducing the original text of the Danish tragedy in this way, the translator deprived it of irony and simplified the conflict. Actually, Hnat Khotkevych's Hamlet does not have much in common with Shakespeare's text, but seems to be more like 'Ur-Hamlet', attributed to Thomas $\mathrm{Kyd}^{20}$ and known as a typical tragedy of revenge. Khotkevych stressed the plot of Hamlet's revenge on Claudius, putting the other conflicts in the shade.

The translator's approach to rendering the stylistic peculiarities of the play is marked with the same radicalism. First and foremost, he refuses to reproduce Shakespearean iambic pentameter in Ukrainian, employing prose instead. As a result, the play loses its metric structure, altering its perception as well.

It is generally acknowledged, that the basic criterion for the quality and adequacy of every Hamlet translation is the famous 'To be or not to be...' soliloquy. Khotkevych cuts it by half, thus refashioning and deconstructing its sense and main ideas.

Гамлет. Жити далі чи разом закінчити життя?.. От питання, що його я не можу рішити. Що благородніше: терпіти удари долі, а чи запротестувати одразу й закінчити життя, заснути?.. Заснути... А далі що? А далі?.. От чому нам загорожено цей шлях. Бо якби знав напевне, що один удар дасть тобі спокій - хто захотів би тоді терпіти й утиск сильного, образи, погорджену любов, забуття заслуг? Хто ніс би тягар життя, хто би хилився під вагою невиносимої праці? От тільки страх чогось о смерті, жах перед тою країною невідомою, звідки ніхто ще не вертався - тільки страх цей і сковує волю, і ми скоріше будемо нести земне горе, ніж відважимося піти в безвість. Отак, коли ми почнемо роздумувати, совість обертає нас на трусів, гасне наша сильна воля і ми шукаємо шляху подалі від цілі. А - Офелія! О, німфо!.. Помьяни й мої гріхи у святій твоїй молитві. ${ }^{21}$

The back-translation reveals the most crucial points of translation:

Hamlet. To live further or to put an end to life at once? This is the question which I cannot solve. What is nobler: to suffer the strikes of fortune or by opposing end the life, to sleep? To sleep... And what is ahead? What is ahead? That is why this way is forbidden for us. For if you knew for sure that one strike would bring you peace - who would bear the oppression of the powerful, offences, despised love, the insolence of office? Who would bear fardels of life, who would bend under the weight of unbearable work? Only the dread of something after death, the undiscovered country, from whose land no traveler returns - only that dread puzzles the will, and makes us bear those ills we have than fly to others that we know not of. For when we start musing, conscience does make cowards of us all, our strong will fades away and we look for the way far from the aim. Ah, Ophelia! Oh, nymph! In thy horizons be all my sins remembered!

20 W. Shakespeare, Hamlet, ed. by H. Jenkins, London 1982, pp. 83-84.

21 В. Шекспір, Гамлет, переклад Г. Хоткевича, "Парадигма" 1998, по. 1, с. 227. 
Hnat Khotkevych acts here as an editor of Shakespeare, imposing much univocity onto the Bard's words. For instance, the translation of the initial line of the soliloquy, which has always been a big issue for generations of translators, is quite simple in Khotkevych's version. For him the problem does not belong to the philosophy of human existence, but to the fact of physical being, which makes the Prince of Denmark a sort of down-to-earth materialist. Also one can notice the absence of key metaphors - 'slings and arrows of outrageous fortune', 'sea of troubles', 'pale craft of thought', etc. - yielding a much simpler and more laconic text.

Besides, two main translation techniques employed by Khotkevych, namely blending, which means conveying several original ideas as a single concept, and generalization, that is substitution of a specific notion with a general one, alter the text, imposing different ideas onto it. While in the original we read

Whether 'tis nobler in the mind to suffer

The slings and arrows of outrageous fortune,

Or to take arms against a sea of troubles,

And by opposing end them? To die: to sleep;

No more; and by a sleep to say we end

The heart-ache and the thousand natural shocks...22

we see the prince hesitate between several variants of the situation development - from 'in the mind to suffer' to 'to take arms against the sea of troubles'. The idea of death/sleep is linked to the previous doubts, as yet another way of dealing with the earthly troubles. In Khotkevych's variant, these components protest, capitulation and death - are blended together: 'What is nobler: to suffer the strikes of fortune or by opposing end the life, to sleep?'. ${ }^{23}$ The translator obviously violates the author's logic: in his variant, opposition means the end of life, sleep, non-existence. Basically, the translator conveys the idea that Hamlet has to stand up against the troubles in Elsinore, and, as a result, die. Thus, Hnat Khotkevych makes the prince proclaim his doom in the middle of the play.

Shortening all of Hamlet's major soliloquies, the translator obviously wanted to make their message more unequivocal and transparent to the reader/spectator. However, he gained quite an unexpected effect: he deprived the tragedy of its authentic multifocal character, leading to a much altered image of the Prince of Denmark: in the translation, Shakespeare's hesitating Hamlet becomes more decisive, brave and cruel - he is just a different character.

Creating his own Hamlet, Khotkevych definitely kept in mind the Ukrainian audience and so made his version sound as authentically Ukrainian as possible. He changed a lot of neutral words into regionally coloured vocabulary, employed a lot of cultural realia to supply the tragedy of the Prince of Denmark with as bright Ukrainian colours as possible. For instance, Shakespeare's Hamlet bitterly explains the treacherous haste of his mother's second marriage with a culinary meta-

22 W. Shakespeare, Hamlet, London 1994, p. 57-62.

23 В. Шекспір, Гамлет, переклад Г. Хоткевича, ор. cit., с. 227. 
phor: ' ...the funeral baked meats/Did coldly furnish forth the marriage tables' ${ }^{24}$ It is quite appropriate to render baked meats with Ukrainian печеня (ресhеnia) which is baked meat. However, Khotkevych employs the name of another dish, which for every Ukrainian is clearly marked as a special treat that definitely could be served both at a wedding and a funeral table, namely, холодеиь (kholodets), which is jellied meat (aspic), usually cooked in winter. Thus, in his version both funeral and marriage tables were "coldly furnished":

Гораиіо. Я приїхав сюди на похорон покійного вашого тата.

Гамлет. А попав на весілля матері...

Гораиіо. Та правда... недовго довелось його чекати.

Гамлет. Хазяйство, друже, хазяйство. Після похорон холодець, бачиш, зостався, так от щоб не пропав... О, пощо я дожив до такого дня!25

In back-translation,

Horatio. I came to see your dead father's funeral.

Hamlet. And you got to my mother's wedding instead...

Horatio. Indeed... It followed hard upon.

Hamlet. Thrift, my friend, thrift. You see, a lot of kholodets remained after the funeral, and in order not to waste it... Oh, why had I ever seen that day!

The substitution of Shakespeare's words with a word bearing national colouring, on the one hand, makes this passage too domesticated. On the other hand, it also alters the genuine Shakespearean point of tension and irony. In Shakespeare's text, the Prince is deeply hurt by the Queen's betrayal, so baked meats serve to stress the unbecoming hurry of the royal action. In Khotkevych's translation for a folk theatre, kholodets gains direct meaning: it may seem that the wedding was organized not as part of Claudius's malicious plan, but because there was simply a need to utilize food remnants. Such implication makes the passage close to popular folk jokes about weddings. Only Hamlet's exclamation of sorrow that follows that slightly burlesque passage returns its general meaning to its tragic course. Another example is a rhymed phrase катюзі по заслузі (ka'tiuzi po za'sluzi) (in back translation - "it serves the torturer right") which Khotkevych introduced instead of Laertes' final words "He is justly served..." ${ }^{26}$ Here the translation is more expressive than the original owing to, first of all, phonetic rhyme and stylistically coloured vocabulary (accusatory "torturer" instead of neutral "he").

Hnat Khotkevych's translating technique yields a very different play, which loses its Medieval/Renaissance context and becomes a tragedy of revenge in the Ukrainian costume. This fits well Khotkevych's ideas of democratic 'folk theatre', for which undoubtedly this translation was created.

\footnotetext{
24 W. Shakespeare, Hamlet, op. cit., pp. 179-180.

25 В. Шекспір, Гамлет, переклад Г. Хоткевича, op. cit., с. 209.

26 W. Shakespeare, Hamlet, op. cit., p. 323.
} 


\section{References}

Doroshenko D., Shakespeare in Ukrainian, "The Slavonic and East European Review" 1931, no. 9 (27), pp. 708-712.

Shakespeare W., Hamlet, Harold Jenkins (ed.), London 1982.

Shakespeare W., Hamlet, London 1994.

Василик-Фурман А., Трагедія В. Шекспіра «Гамлет» у перекладі М. Руднищького, в: В. Шекспір, Гамлет, Львів 2008, с. 5-18.

Кізченко В., Хоткевич Гнат Мартинович, в: Енциклопедія історії Украӥни, y 10 томах, том 10: Т-Я, Київ 2013, с. 424.

Ковальчук Л., 3 приводу однієї постановки (рецензія Гната Хоткевича на «Макбет»ЛесяКурбаса), http://www.kurbas.org.ua/projects/almanah7/14_1_k. pdf (accessed: 12 January 2018).

Козак Б., Палімпсест украӥнського «Гамлета: переклад Михайла Рудницького i прапрем'єра у Львові 1943 року, в: В. Шекспір, Гамлет, Львів 2008, c. $170-188$.

Коломієць Л., Українські перекладачі «Гамлета» В. Шекспіра: Пантелеймон Куліш, Юрій Клен, Леонід Гребінка, Михайло Рудницький, Ігор Костеиький, Григорій Кочур, Юрій Андрухович, “Ренесансні студії” 2009, по. 12-13, c. $163-188$.

Коломієць Л., Новий украӥнський «Гамлет»: перекладащька стратегія Юрія Андруховича, "Мова і культура" 2005, vol. 8, no. 3 (2), с. 349-356.

ЛучукО., Діалогічна природалітератури. Перекладознавчі та літературознавчі нариси, Львів 2004.

Мороз М., В. Шекспір в Украӥнській РСР, в: В. Шекспір, Твори в шести томах, т. 6, Київ 1998, с. 803-832.

Реальные училищуа, Энциилопедический словарь Брокгауза и Ефрона, https:// ru.wikisource.org/wiki/ЭСБЕ/Реальные_училища (accessed: 21 April 2018).

Самчинська Т., Гнат Хоткевич: німецький шпигун із бандурою, https://vsiknygy. net.ua/person/5962/ (accessed: 20 April 2018).

Черняк Ю., Специфіка актуалізації ціннісної семантики «Гамлета» В. Шекспіра в українському шекспірівському дискурсі, Київ 2011.

Шекспір В., Гамлет, переклад Г. Хоткевича, “Парадигма” 1998, no. 1, с. 208-252.

Шекспір В., Гамлет, переклад М. Рудницького, Львів 2008. 